\title{
Effect of heat stress in late gestation on subsequent lactation performance and mammary cell gene expression of Saanen goats
}

\author{
H. B. Hooper, ${ }^{1}$ P. dos S. Silva, ${ }^{1}$ S. A. de Oliveira, ${ }^{1}$ G. K. F. Meringhe,${ }^{1}$ P. Lacasse,${ }^{2}$ and J. A. Negrão ${ }^{1 *}$ \\ ${ }^{1}$ Department of Basic Sciences, Faculty of Animal Science and Food Engineering, University of São Paulo, Pirassununga, São Paulo, Brazil, \\ $13635-900$ \\ ${ }^{2}$ Sherbrooke Research and Development Centre, Agriculture and Agri-Food Canada, Sherbrooke, Quebec, Canada, J1M 0C8
}

\section{ABSTRACT}

Little is known about the effects of heat stress during the late gestation period on lactation in dairy goats. For this reason, 32 Saanen goats were randomly assigned to 1 of 2 groups, control (CT; $\mathrm{n}=16$ ) or heat stress (HS; $\mathrm{n}$ $=16$ ), during late gestation. The HS goats were housed in a climatic chamber before parturition and subjected to heat stress for the last $45 \mathrm{~d}$. After parturition, the HS goats were housed in the same conditions as the CT group. Mammary gland biopsies were performed on 7 goats per treatment at $-30,-15,15$, and $30 \mathrm{~d}$ relative to parturition, so that the expression levels of several genes could be determined. The HS goats produced less milk than the CT goats did during the first half of lactation, but not during the rest of lactation. Before parturition, apoptosis-related transcripts (TP53 and $B A X$ ) were higher in the mammary glands of the HS goats than in those of the CT goats. The HS goats also had higher levels of $H S P B 1$ gene expression during gestation and lactation. However, expression of the prolactin receptor gene was lower after parturition in the mammary glands of HS, suggesting downregulation of prolactin signaling. In summary, heat stress during final gestation reduces milk yield in the subsequent lactation. Although the upregulation of apoptosis signaling in the HS goats suggests that heat stress affects mammary cell number, the loss of the effect on milk production is more compatible with an effect on cell activity, which could be due to a downregulation of prolactin signaling.

Key words: milk yield, prolactin, dry period, mammary gland

Received April 2, 2019.

Accepted October 7, 2019.

*Corresponding author: jnegrao@usp.br

\section{INTRODUCTION}

The effects of climate change on livestock are becoming more relevant every year since climate exposes animals to conditions beyond their thermal neutral zone (IPCC, 2013; Belhadj Slimen et al., 2016). A reduction in animal productivity caused by heat stress has been frequently described in cattle (Kadzere et al., 2002; West, 2003; Mader et al., 2006; Tao et al., 2012; Collier et al., 2017). Dairy goats under moderate to severe heat stress at lactation have reduced milk yield, as well as fat, protein, lactose, and TS contents of milk (Sano et al., 1985; Brasil et al., 2000). In cows, the negative effects of heat stress are not only associated with the lactation period, but milk production in the following lactation is also affected during late gestation (Tao and Dahl, 2013). However, little is known about the effects of chronic heat exposure in late gestation on the subsequent milk yield of dairy goats.

The losses caused by heat stress are related to several biological responses necessary for the maintenance of thermal equilibrium and homeostasis. The mechanism by which heat stress in late gestation affects subsequent milk yield is not fully elucidated. Considering that milk yield depends on the number and activity of epithelial cells (Capuco et al., 1997; Nørgaard et al., 2008), it is possible that heat stress negatively affects milk yield through an effect on mammary cell number and the relation between apoptosis and proliferation (Rowson et al., 2012).

In vitro, thermal stress reduced mammary epithelial cell viability accompanied by apoptosis, lower B-cell lymphoma 2 (BCL2)/BCL-2-like protein $\mathrm{X}(B A X)$ ratio, and reduced mitochondrial membrane potential (Du et al., 2008). Nevertheless, no significant difference in apoptosis rate was found in mammary epithelial cells in cows submitted to heat stress (Tao et al., 2011). In contrast, the higher synthesis of heat shock proteins (HSP) protects cells from damage (Neuer et al., 2000; Mohanarao et al., 2014; Dangi et al., 2016). During the apoptosis process, HSP act in different stages of the 
Table 1. Ingredient composition of TMR for goats in both the gestation and lactation periods

\begin{tabular}{lccc}
\hline & & \multicolumn{2}{c}{ Lactation } \\
\cline { 2 - 4 } Ingredient (\% of DM) & Gestation & Early & Middle/late \\
\hline Corn silage & 39 & 36 & 39 \\
Coast cross hay & 21 & 19 & 21 \\
Corn meal & 27.2 & 25.2 & 22.4 \\
Soybean meal & 8 & 15.7 & 1 \\
Soy oil & 0.4 & 1.2 & 2.6 \\
Mineral and vitamin mix ${ }^{1}$ & 4.4 & 2.9 & 14 \\
${ }^{1}$ The mineral and vitamin mix contained the following: Ca (maximum), 146 g; Ca (minimum), 48 g; Cu (mini- \\
mum), 500 mg; Cr (minimum), 10 mg; S (minimum), 15 g; Fe, 2,000 mg; F (maximum), 850 mg; P (minimum), \\
85 mg; I (minimum), 75 mg; Mg (minimum), 15 mg; Mn (minimum), 1,400 mg; Se (minimum), 140 g; Zn \\
(minimum), 4,400 mg.
\end{tabular}

death signaling (Garrido et al., 2001). They are related to cellular survival during climate challenges (Bahr et al., 2014; Ozaydin et al., 2016; Shochet et al., 2016).

Similar to heat stress, long-day photoperiod during late gestation is associated with lower milk yield during the following lactation (Auchtung et al., 2005; Lacasse et al., 2014). Long-day photoperiod during the dry period increases blood prolactin (PRL) and decreases the expression of PRL receptors in mammary glands during the following lactation (Auchtung et al., 2005). Given that heat stress is associated with higher PRL levels, a reduction in mammary gland responsiveness to PRL might be a factor for the effect of late-gestation heat stress on milk production.

Hence, we hypothesized that heat stress during late gestation negatively impairs the subsequent milk performance of dairy goats, and this effect is part due to changes in apoptosis and HSP signaling of the mammary epithelial cells. Therefore, our study aimed to evaluate the effects of heat stress during late gestation on milk yield and composition during the following lactation in dairy goats.

\section{MATERIALS AND METHODS}

\section{Ethical Approval and Experimental Site}

All animal procedures were approved by the Animal Ethics Committee (protocol 3709280316) of the Faculty of Animal Science and Food Engineering, University of São Paulo, which adheres to Brazilian federal law.

The experiment was conducted from May 2016 to March 2017 at the Laboratory of Animal Physiology in Pirassununga, Brazil $\left(21^{\circ} 58^{\prime} \mathrm{S}, 47^{\circ} 26^{\prime} \mathrm{W}\right)$. This climate is categorized as subtropical humid (Köppen-Geiger classification), with an annual rainfall of 1,238 $\mathrm{mm}$. Air temperature and relative humidity were measured every 30 min using a LogBox-RHT-LCD data logger (Novus, Miami, FL). The temperature-humidity index (THI) was calculated using the following equation: $\mathrm{THI}=[0.8$ $\times$ air temperature $\left.\left({ }^{\circ} \mathrm{C}\right)\right]+[(\%$ relative humidity $/ 100)$ $\times$ (air temperature -14.4$)]+46.4$ (Buffington et al., 1981).

\section{Animals, Experimental Design, and Housing}

Healthy, multiparous, pregnant Saanen goats were randomly assigned to 1 of 2 groups: control $(\mathbf{C T}$; $\mathrm{n}=$ 16) and heat stress (HS; $n=16)$. Average BW (mean \pm SEM) was recorded before the experiment began $(\mathrm{CT}: 65.71 \pm 2.16 \mathrm{~kg}$; HS: $61.94 \pm 2.76 \mathrm{~kg} ; P=0.29$ ). For the CT and HS goats, respectively, the BCS were $3.26 \pm 0.17$ and $3.10 \pm 0.20(P=0.55)$, the number of lactations were $1.28 \pm 1.18$ and $1.13 \pm 1.09(P=0.27)$, and average daily milk production amounts during the previous lactation (35 wk) were $2.0 \pm 0.25$ and $1.9 \pm$ $0.22 \mathrm{~kg} / \mathrm{d}(P=0.83)$. All goats were fed twice a day (0800 and $1500 \mathrm{~h}$ ) a TMR (corn silage, hay, and mixed grains) containing roughage and concentrate on a DM basis (Table 1) to provide their nutritional requirement (NRC, 2007). Adjustments were made weekly considering the BW and production phase (gestation or lactation), and the feed bunks were checked to guarantee leftovers.

The experiment was conducted from $60 \mathrm{~d}$ before parturition until the end of the following lactation (35 wk). After enrollment, a 15-d adaptation period was provided, when the goats could become familiarized with their new environment and the social hierarchy. The CT and HS goats were housed in 2 adjacent pens (50 $\mathrm{m}^{2}$ each, with stocking density of $3 \mathrm{~m}^{2}$ /animal). The CT animals were in a covered pen, with a concrete floor with wood platform bedding and fence walls that allow air flow. The HS animals were in a climatic chamber, with a concrete floor with wood platform bedding, walls, and ceiling (Supplemental Figure S1; https://doi .org/10.3168/jds.2019-16734). 
The climatic chamber had a heat system (Mipal Industry LTDA, Cabreúva, Brazil) that allowed the manual set-up of air flow and the increase and maintenance of air temperature. To induce heat stress, the air conditioning system was preset to turn on at 1000 $\mathrm{h}$ and turn off at $1600 \mathrm{~h}$, and achieve the air temperature of $37^{\circ} \mathrm{C}$, all regulated by a timer and thermostats. Both areas were illuminated from 0700 to $1800 \mathrm{~h}$ by fluorescent lights with approximately 100-lx intensity at the goats' eye level. The relative humidity was not manipulated. After parturition, the heating system was turned off to allow HS to return to thermoneutral conditions comparable to the CT goats. The conditions described here are based on a previous study conducted on Saanen goats (Hooper et al., 2018).

The level of heat load for CT and HS was evaluated by measuring the physiological parameters, rectal temperature $(\mathbf{R T})$ and respiratory frequency $(\mathbf{R F})$ pre- and post-kidding at $1500 \mathrm{~h}$. The RT was measured with a calibrated clinical thermometer (TermoMed, Incoterm, C. Technology Ltd., Porto Alegre, Brazil) with a precision of $\pm 0.10^{\circ} \mathrm{C}$. The $R F$ was evaluated with a stethoscope placed on the intercostal space counting the breath movements for $60 \mathrm{~s}(\mathbf{b p m})$. Pre- and postkidding, the physiological parameters (RT and RF) were measured to confirm the effectiveness of the HS treatment, as reported by Silva (2000) and Pereira et al. (2011).

\section{Lactation Measurements}

Body weight and BCS were monitored before $(\mathrm{d}$ $-60)$, during (d $-45,-30$, and -15$)$, and after (d $15,30,45$, and 60 ) the heat challenge. The BCS was evaluated by palpating the ribs and side of the spine, and the animals were classified as very thin (1), thin (2), normal (3), fat (4), or very fat (5), following the method of Santucci and Maestrini (1985).

The goat kids were separated from their mothers after birth and received colostrum and milk by artificial feeding, from 10 to $20 \%$ in relation to the BW per day, in bottles. The goats were milked twice daily (at 0600 and $1700 \mathrm{~h}$ ), with a mechanical milking machine (GEA Westfalia Surge, Bönen, Germany) regulated to maintain a vacuum level of $48 \mathrm{kPa}$ and a pulse rate of 120 cycles/min. Before milking, the gland was tested for mastitis, pre-dipped, and dried. The machine was attached to the teat until the milking was complete.

Milk was weekly sampled from the milk collector to determine the milk composition and SCC. On average, goats were $5.30 \pm 0.25 \mathrm{DIM}$ at first sampling. The milk content fat, lactose, protein, water, and minerals were determined using MilkScope Expert equipment
(Razgrad, Bulgaria). Milk acidity was determined by the Dornic method, using the following equation: acidity $($ in $\mathrm{dg} / \mathrm{L}$ of lactic acid $)=\mathrm{V}($ titrant $) \times 10$. The $\mathrm{SCC}$ was determined on $10 \mu \mathrm{L}$ of milk by direct microscopy using pyronin Y-methyl green stain (Raynal-Ljutovac et al., 2007). The SCC was calculated by counting the leukocytes on the microscopic slice, multiplying this number by the microscope factor, and converting the final result into a log scale.

Once per week, milk samples were aseptically collected from both teats in a sterile tube for microbiological content analysis. Microbiological analysis was performed in 3 different culture media, with $0.1 \mathrm{~mL}$ of pure milk. The total colony counts were obtained by spreading the samples onto plate count agar and BairdParker agar plates supplemented with egg yolk tellurite emulsion for identifying Staphylococcus aureus and MacConkey agar for identifying gram-negative enteric bacilli (Enterobacteriaceae). The plates were incubated at $37^{\circ} \mathrm{C}$ for $48 \mathrm{~h}$, after which the colonies were counted as units per milliliter.

\section{Mammary Gland Biopsies}

Mammary biopsies were collected from a subset of 7 goats per treatment at $-30,-15,15$, and $30 \mathrm{~d}$ relative to parturition, alternating mammary rare quarters between time points. Before the biopsy procedure, goats received i.m. injections of an anti-inflammatory $(1 \mathrm{mg} /$ kg, Diclofenaco 50, Ourofino, São Paulo, Brazil) and an antibiotic (5 mg/kg, Gentamax, Ceva, São Paulo, Brazil). An area of skin at the rear of the gland was shaved and disinfected following the sequence of $70 \%$ alcohol, $10 \%$ povidone-iodine, and $70 \%$ alcohol. The incision area was subcutaneously injected with $1 \mathrm{~mL}$ of $2 \%$ lidocaine (Anestésico L, Pearson Saúde Animal, São Paulo, Brazil). A small incision $(<1 \mathrm{~cm})$ was made with a scalpel (blade number 15) in the skin and capsule of the udder, after which the core biopsy was performed with a biopsy needle (C1410A, $22 \mathrm{~mm}, 14$ Ga; Bard Biopsy, Tempe, AZ), and the skin was closed with a simple interrupted nondegradable suture. Three samples $(100 \mathrm{mg})$ were obtained in the same area but at different angles. The tissue was transferred into a sterile tube containing PBS.

At the laboratory, these samples were stored at $-80^{\circ} \mathrm{C}$ until further analysis. After the procedure, the incision was topically treated with anti-inflammatory/antibiotic spray (Terra-Cortril, Zoetis, São Paulo, Brazil) and antiseptic (Aerocid Total, Agener, São Paulo, Brazil) once per day. The mammary glands were milked daily to discard eventual clots and prevent infection; moreover, animal health was checked twice a day by monitoring 
Table 2. Primer sequences and amplicon size of each gene analyzed in goat's peripheral blood mononuclear cells by quantitative real-time PCR

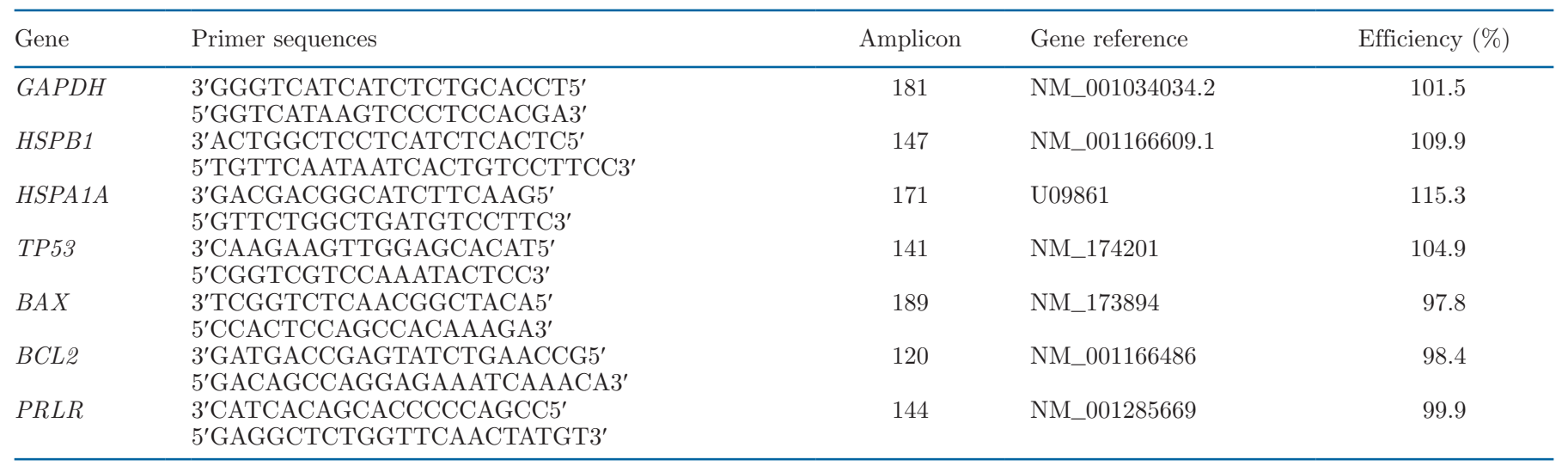

the RT and signs of infection until the tissue healing in approximately $7 \mathrm{~d}$. The suture was removed after $10 \mathrm{~d}$.

\section{Gene Expression}

Total RNA was extracted and purified using a PureLink RNA Mini Kit (Invitrogen, Carlsbad, CA). The concentrations were determined by Qubit 2.0 Fluorometric Quantitation (Thermo Fisher Scientific, Wilmington, DE). The obtained material was treated with RNase-free DNase (Promega, Madison, WI) to prevent genomic DNA contamination. The RNA was reversetranscribed into cDNA using the GoScript Reverse Transcriptase Kit (Promega). The relative gene expression levels of heat shock proteins 27 (HSPB1) and 70 (HSPA1A), B-cell lymphoma 2 (BCL2), BCL-2-like protein $\mathrm{X}(B A X)$, tumor protein 53 (TP53), and prolactin receptor long isoform $(P R L R)$ were determined by quantitative real-time PCR using the StepOne RealTime PCR System (Invitrogen), using the primers described in Table 2. SYBR Green (Invitrogen) was used as the fluorescent label with a reaction volume of $20 \mu \mathrm{L}$ in 96-well plates (Invitrogen) sealed with transparent adhesive tape.

The $20-\mu \mathrm{L}$ reaction mixture was composed of $1 \mu \mathrm{L}$ of cDNA (mean concentration of $10 \mathrm{ng} / \mu \mathrm{L}$ ), $10 \mu \mathrm{L}$ of SYBR Green, $0.4 \mu M$ primer pair, and $8.2 \mu \mathrm{L}$ of ultrapure water. For all genes, the quantitative PCR conditions were as follows: incubation stage $\left(95^{\circ} \mathrm{C}\right.$ for $10 \mathrm{~min}) ; 40$ cycles of temperature increases and the separation of double-stranded nucleic acids $\left(95^{\circ} \mathrm{C}\right.$ for $15 \mathrm{~s})$; annealing, primer binding $\left(60^{\circ} \mathrm{C}\right.$ for $\left.1 \mathrm{~min}\right)$; and dissociation. Each primer pair tested had one single peak in the melt curve, and the housekeeping gene had similar expression between treatments and across time. The relative gene expression was quantified using the $2[$-delta delta $\mathrm{C}(\mathrm{T})]$ method for comparing the expres- sion level of the target genes with the reference one $(G A P D H)$ and the cycle threshold of the control at each specific time point (Livak and Schmittgen, 2001). For every set of primers, the PCR efficiency was close to $100 \%$, and the specificity of the primer pairs was confirmed by melting curve analysis and appropriate size, using $1.5 \%$ agarose gel electrophoresis.

\section{Statistical Analysis}

Data were analyzed using the SAS software package (version 9.2, SAS Institute Inc., Cary, NC). The normality of the data was tested using the ShapiroWilk test. Data were analyzed by ANOVA using the MIXED procedure of SAS (SAS Institute Inc.). Time was used as a repeated effect and goat was used as the subject. An ANOVA for the physiological data, weight, and BCS was conducted separately for the gestation and the lactation periods. The daily milk yield was averaged per week before analysis. The effects of heat stress on milk yield was analyzed using previous lactation milk production as a covariate. When the whole lactation $(35 \mathrm{wk})$ was analyzed, a treatment $\times$ time interaction was presented. To remove the interaction, the lactation was divided into 4 periods and reanalyzed using, again, the MIXED procedure as repeated measurements. The periods were wk 1, 2, and 3 (early), wk 4 to 12 (plateau), wk 13 to 24 (middle), and wk 25 to 35 (late). Energy-corrected milk was calculated by following the equation: $\mathrm{ECM}=[0.327 \times$ milk yield $(\mathrm{kg} / \mathrm{d})]+[12.86 \times$ fat yield $(\mathrm{kg} / \mathrm{d})]+[7.65 \times$ protein yield $(\mathrm{kg} / \mathrm{d})]$ (Flores et al., 2009). The gene expression statistical analysis was conducted by time, using the MIXED procedure in SAS. When an effect was determined to be statistically significant, the means of data were compared using Fisher's test with the threshold for significance set at $P \leq 0.05$. $P$-values $>0.05$ and 


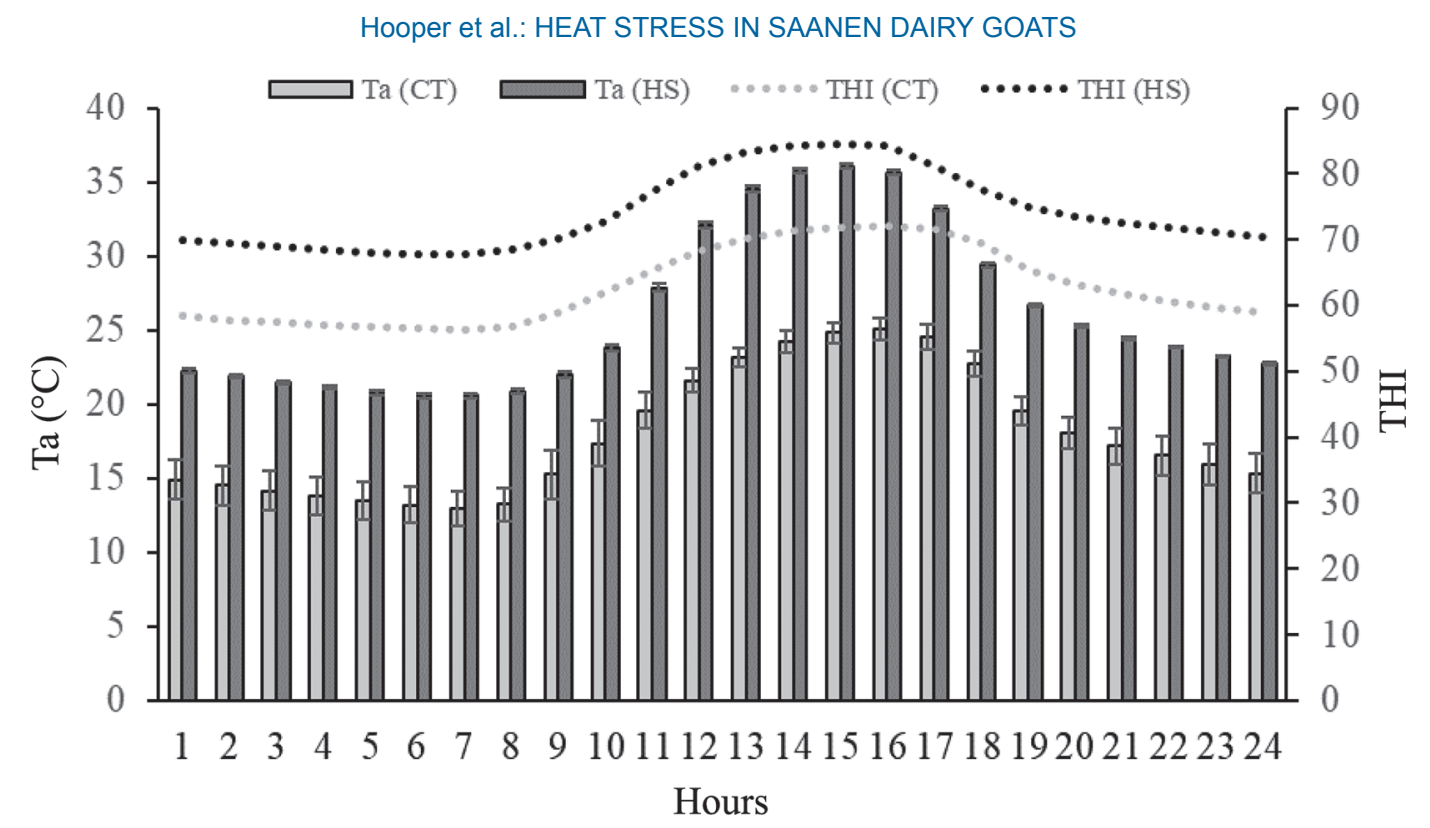

1986

Figure 1. Mean and SEM of air temperature (Ta) and temperature-humidity index (THI) for the control (CT) and heat-stressed (HS) goats during the heat challenge, per hour.

$\leq 0.1$ were considered a trend. The results are presented as $\mathrm{LSM} \pm \mathrm{SEM}$.

\section{RESULTS}

\section{Animal Performance}

From 1000 to $1600 \mathrm{~h}$, the mean Ta and THI were, respectively, $33.6^{\circ} \mathrm{C}$ and 82.27 for the $\mathrm{HS}$ group, and $23.3^{\circ} \mathrm{C}$ and 70.07 for the CT group. The Ta and THI were higher for the HS group than for the CT group $(P<0.01$; Figure 1$)$. Heat stress did not affect BW or BCS (Table 3). Pre-kidding, HS had higher RT (CT: $\left.38.82^{\circ} \mathrm{C} \pm 0.02 ; \mathrm{HS}: 39.22^{\circ} \mathrm{C} \pm 0.03 ; P<0.001\right)$ and $\mathrm{RF}$ (CT: $84.00 \mathrm{bpm} \pm 2.39$; HS: $136.53 \mathrm{bpm} \pm 2.85$;
$P<0.001)$ than CT. Post-kidding, no difference was observed for RT $\left(\mathrm{CT}\right.$ : $39.05^{\circ} \mathrm{C} \pm 0.05$; HS: $39.15^{\circ} \mathrm{C} \pm$ $0.05 ; P=0.28)$ and RF (CT: 86.95 bpm \pm 3.85 ; HS: $90.61 \mathrm{bpm} \pm 3.2 ; P=0.99)$.

Heat stress had no effect on milk yield considering the complete lactation and the first 3 wk of lactation $(P=0.47$; Figure 2). However, from wk 4 to 12 , the CT goats tended to produce more milk than the HS goats (2.31 vs. $1.92 \mathrm{~kg} / \mathrm{d}$, respectively; $P=0.06)$. Furthermore, from wk 13 to 24 , the $\mathrm{CT}$ goats produced more milk than the HS goats $(1.99$ vs. $1.47 \mathrm{~kg} / \mathrm{d} ; P=0.03)$. Heat stress had no effect $(P=0.9)$ on milk yield for the HS goats after wk 25.

Treatment had no effect on milk protein content (Table 4). Lactose concentration in milk was lower $(P$

Table 3. Effect of heat stress during late gestation on BW and BCS in late gestation and during lactation for control $(\mathrm{CT} ; \mathrm{n}=16)$ and heatstressed (HS; $\mathrm{n}=16)$ multiparous goats $(\mathrm{LSM} \pm \mathrm{SEM})$

\begin{tabular}{|c|c|c|c|c|c|c|}
\hline Day $^{1}$ & \multicolumn{3}{|c|}{ BW (kg) } & \multicolumn{3}{|c|}{ BCS } \\
\hline-60 & $73.68 \pm 2.80$ & $67.19 \pm 3.33$ & 0.15 & $2.82 \pm 0.15$ & $3.17 \pm 0.22$ & 0.19 \\
\hline-45 & $77.10 \pm 3.11$ & $70.59 \pm 3.29$ & 0.16 & $2.76 \pm 0.15$ & $2.95 \pm 0.16$ & 0.41 \\
\hline-30 & $78.57 \pm 3.85$ & $74.44 \pm 3.41$ & 0.43 & $2.75 \pm 0.21$ & $2.78 \pm 0.23$ & 0.92 \\
\hline-15 & $84.82 \pm 3.27$ & $76.47 \pm 3.76$ & 0.11 & $3.03 \pm 0.22$ & $2.97 \pm 0.19$ & 0.82 \\
\hline 30 & $68.79 \pm 2.35$ & $63.09 \pm 3.31$ & 0.18 & $2.69 \pm 0.24$ & $2.79 \pm 0.19$ & 0.74 \\
\hline 45 & $70.54 \pm 2.54$ & $66.34 \pm 3.25$ & 0.33 & $2.91 \pm 0.21$ & $2.91 \pm 0.17$ & 0.98 \\
\hline 60 & $78.21 \pm 2.90$ & $69.98 \pm 3.67$ & 0.10 & $3.09 \pm 0.26$ & $3.15 \pm 0.26$ & 0.87 \\
\hline
\end{tabular}

${ }^{1}$ Relative to kidding. 


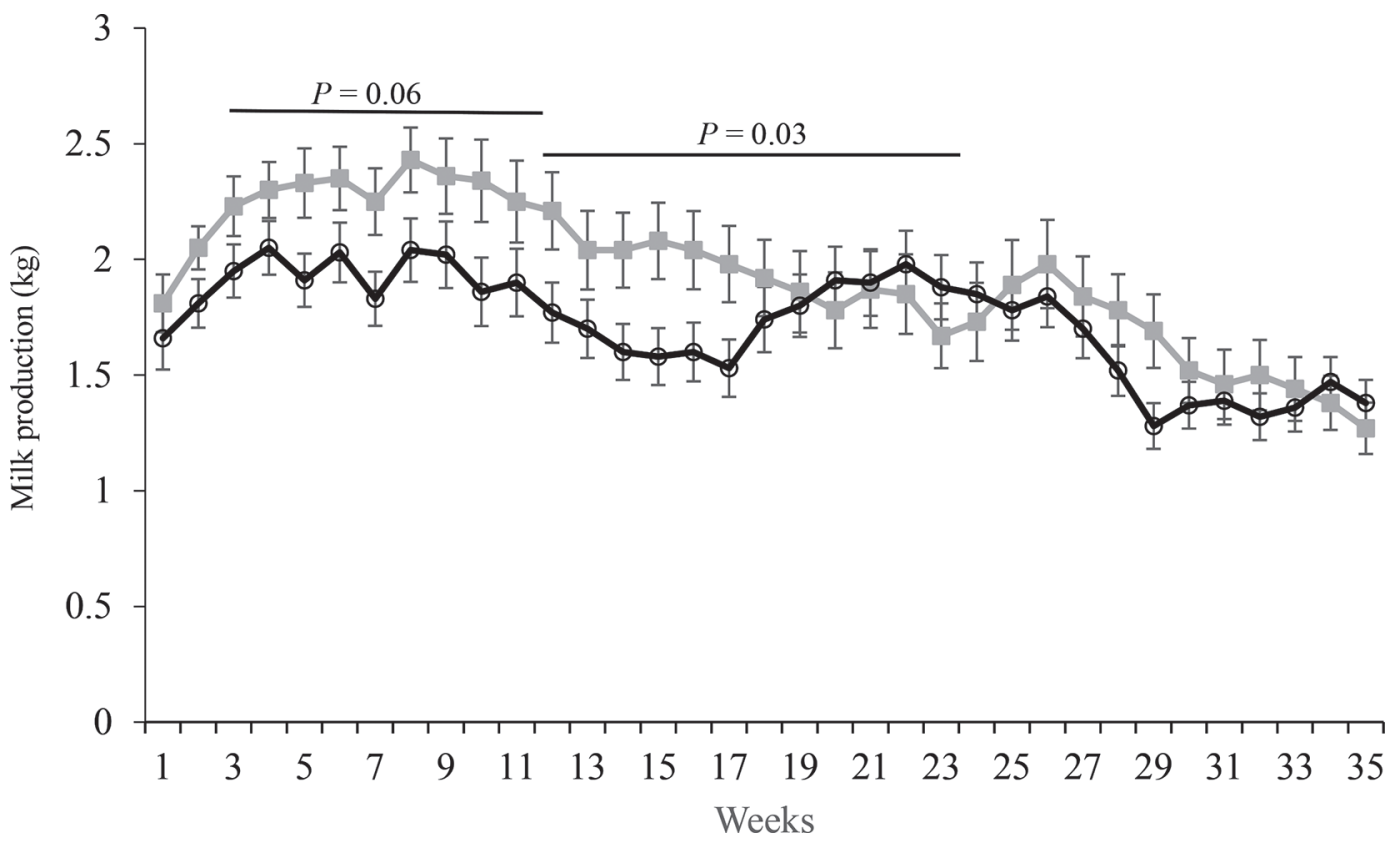

Figure 2. Effect of heat stress during late gestation on milk yield for control $(\mathrm{CT}, \boldsymbol{\square}, \mathrm{n}=16)$ and heat-stressed $(\mathrm{HS}, \mathrm{O}, \mathrm{n}=16)$ multiparous goats during 35 wk of lactation. Error bars represent SEM.

$=0.003)$ for the HS goats than for the $\mathrm{CT}$ goats during the first $3 \mathrm{wk}$ of lactation. In contrast, milk fat content was higher for the HS goats than for the CT goats from wk 4 to $12(P=0.01$; Table 4$)$. The ECM tended $(P=$ $0.09)$ to be greater for the CT goats from wk 4 to 12 .

Throughout the lactation period, the HS goats had greater SCC than the CT goats $(P<0.001$; Table 4$)$. Nevertheless, the percentage of glands infected and bacterial counts were similar for both groups (data not shown).

\section{Gene Expression Response}

During gestation, greater gene expression of TP53 on $\mathrm{d}-30(P=0.03), B A X$ on $\mathrm{d}-15(P=0.03), H S P B 1$ on $\mathrm{d}-15(P=0.02)$, and $P R L R$ on $\mathrm{d}-15(P=0.02)$ was observed in the mammary glands of the HS goats compared with CT (Table 5). A trend $(P=0.08)$ was observed for greater expression of the BCL2 gene on d -15 . On d 15 of lactation, greater expression of the $H S P B 1$ gene $(P=0.01)$ and lower expression of the

Table 4. Effect of heat stress during late gestation on milk yield (MY, kg), ECM (kg/d), fat (\%), protein (\%), lactose (\%), minerals (MIN; \%), lactic acid $(\mathrm{Ac} ; \%)$, and SCC $\left(\log _{10}\right)$ for control (CT; $\left.\mathrm{n}=16\right)$ and heat-stressed (HS; $\mathrm{n}=16$ ) multiparous goats in different lactation periods (data are presented as LSM)

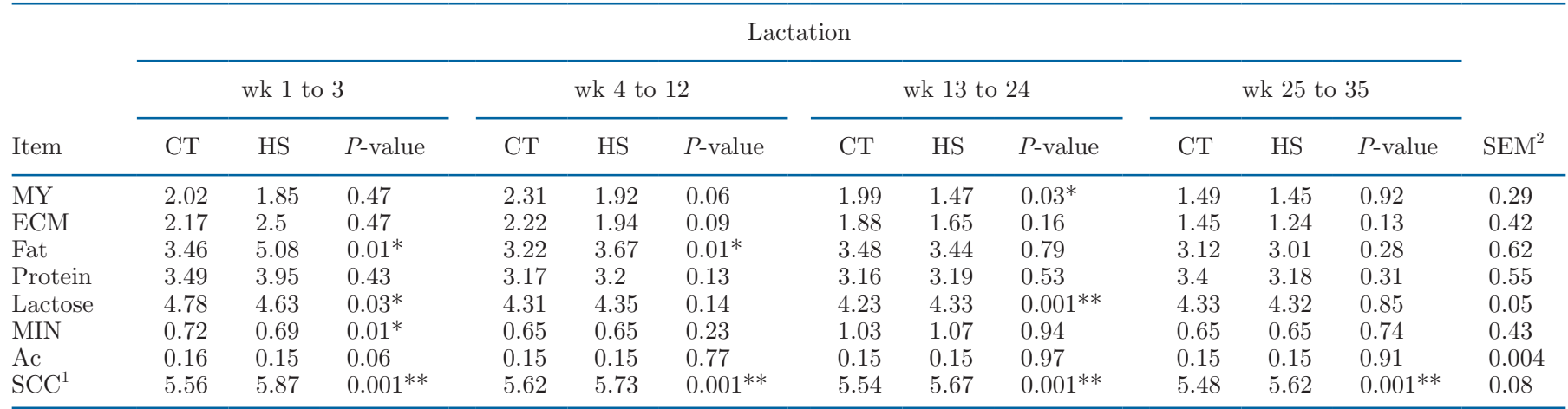

${ }^{1}$ Values presented as $\times 10^{3} / \mathrm{mL}$.

${ }^{2}$ Pooled SEM $\leq$.

${ }^{*} P \leq 0.05,{ }^{* *} P \leq 0.001$ within treatments for the same weeks of lactation. 
Table 5. Effect of heat stress during late gestation on mammary gland relative gene expression of TP53, BAX, BCL2, HSPB1, HSPA1A, PRLR, and the ratio of $B A X: B C L 2$ for control $(\mathrm{CT} ; \mathrm{n}=7)$ and heat-stressed (HS; $\mathrm{n}=7$ ) multiparous goats, during gestation and lactation (LSM \pm SEM)

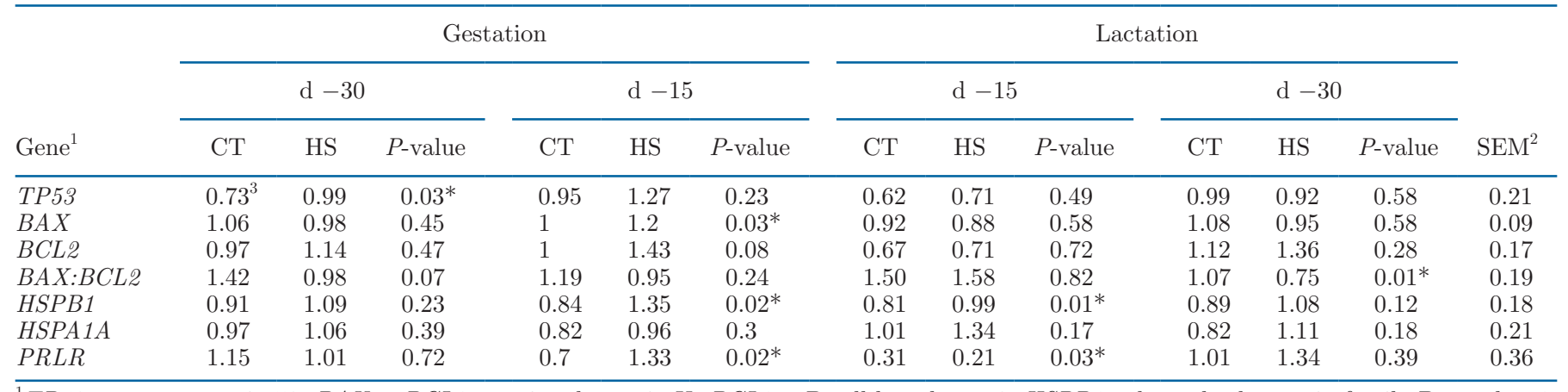

${ }^{1} T P 53=$ tumor protein 53; BAX = BCL2-associated protein X; BCL2 = B-cell lymphoma $2 ; H S P B 1=$ heat shock protein family B member 1 ; $H S P A 1 A=$ heat shock protein family A member $1 \mathrm{~A} ; P R L R=$ prolactin receptor (long isoform).

${ }^{2}$ Pooled SEM $\leq$.

${ }^{3}$ Relative gene expression. Lower delta cycle threshold (DCT) values indicate lower expression.

$* P \leq 0.05$ within treatments for the same day relative to parturition.

PRLR gene $(P=0.03)$ were observed in the mammary glands of the HS goats than in those of the CT goats. Although no effect was observed on $B C L 2$ and $B A X$ expression during lactation, the $B A X: B C L 2$ ratio was higher on d 30 in the HS goats than in the CT goats.

\section{DISCUSSION}

During the last third of gestation, the HS goats were exposed to an environment in which the thermal load was above the comfort temperature of goats (20 to $30^{\circ} \mathrm{C}$ ) and was higher than that of the CT goats (Silva, 2000; Pereira et al., 2011) for several hours per day. For the HS and CT groups, the THI values were 82.3 and 70.0, respectively, which are considered an alert condition for the HS goats and typical for the CT goats (Silanikove and Koluman, 2015). In Saanen and Alpine goats, moderate to severe heat stress is reached when the THI is between 79 and 89 (Sano et al., 1985; Brown et al., 1988).

Physiologically, the heat challenge caused an increase of RT and RF to maintain homeothermy. Under heat stress, the HS goats increased heat loss mostly by respiration to keep RT within the physiological range (38.5 to $39.7^{\circ} \mathrm{C}$; Silva, 2000; Pereira et al., 2011). In AngloNubian goats, no changes in rectal or skin temperature were observed when the air temperature was between 22 and $26^{\circ} \mathrm{C}$, but when the air temperature was higher than $30^{\circ} \mathrm{C}$, goats maintained thermal equilibrium by latent mechanisms: evaporation and respiration (Maia et al., 2016). In the present experiment, the heat stress was confirmed by the elevation of $\mathrm{RF}$ when the air temperature was above $30^{\circ} \mathrm{C}$.
Milk production was decreased by previous exposure to heat stress in late gestation. Mabjeesh et al. (2013) reported that short day photoperiod handling when dry goats are under heat load can be used as a strategy to decrease the carryover effect of heat stress in subsequent lactation. In keeping with that result, several studies in cows reported a reduction in milk yield following heat stress in late gestation (Adin et al., 2009; do Amaral et al., 2009; Tao et al., 2011, 2012; Karimi et al., 2015). In our study, the goats exposed to heat stress produced $16 \%$ less milk (39.5 kg) during the entire experimental lactation period. In cows, a milk yield reduction of $5.3 \%$ was observed in the first $90 \mathrm{~d}$ of lactation when the animals were not cooled during the dry period and late gestation (Adin et al., 2009). Also, heat stress abatement during pre-parturition increased milk yield by $3.5 \%(84.3 \mathrm{~kg} / \mathrm{cow})$ in the first $60 \mathrm{~d}$ of lactation (Urdaz et al., 2006). Even though goats present better thermoregulatory mechanisms than cows do when under heat stress (Silanikove, 2000; Shilja et al., 2016; Sarangi, 2018), our results and those of Mabjeesh et al. (2013) suggest that heat stress is as detrimental for milk production in goats as in cows.

The SCC was higher for the HS goats than for the CT goats during the entire lactation period. The SCC has been widely measured in dairy ruminants as an indicator of udder health and IMI (Baudry et al., 1997; Sharif and Muhammad, 2008; Sant'anna and Paranhos da Costa, 2011). In comparison with cows, goats present higher numbers of cells in their milk, and healthy dairy goats have a larger range in SCC, which can reach 1 million cells $/ \mathrm{mL}$ without any evidence of mastitis (Paape et al., 2001; Raynal-Ljutovac et al., 2007; Barrón-Bravo 
et al., 2013). Although udder health is related to SCC, other count parameters need to be taken into account (Leitner et al., 2008). The HS and CT goats had fewer than 600,000 cells in all the lactation phases, a count that is considered healthy. The reduction in milk yield caused by the treatment was not due to mastitis because the incidences of clinical mastitis and IMI were low and unaffected by the treatment. These findings are similar to those from another study that did not observe any differences in SCC and microbiology status after different stressors were applied to Saanen goats (Bomfim et al., 2018).

As stated previously, milk production depends on the number of secretory cells. Before parturition, the HS goats expressed higher levels of TP53 on $\mathrm{d}-30$ of gestation. A pro-apoptotic protein, TP53, is stimulated in response to cellular damage during mammary gland involution (Levine, 1997; Green and Streuli, 2004; Avivar-Valderas et al., 2014). Higher TP53 transcript levels were previously observed in bovine mammary epithelial cells maintained in vitro at $42^{\circ} \mathrm{C}(\mathrm{Hu}$ et al., 2016). Furthermore, TP53 accumulates in mammalian cells during environmental stress, likely in response to DNA damage (Ohnishi et al., 1999). Our study also observed higher expression levels of pro-apoptotic gene $B A X$ in the HS goats on $\mathrm{d}-15$ of gestation. The higher expression of the $B A X$ gene is related to the expression of the TP53 gene (Green and Streuli, 2004). Nevertheless, the expression of the anti-apoptotic gene BCL2 also tended to be elevated in the HS goats, with the result that the $B A X: B C L 2$ ratio was not affected. Biologically, the greater ratio of $B A X: B C L 2$ means that the intrinsic via of apoptosis are guided to the cell death, with more BAX expressed in the mitochondria outer membrane and it is associated with the release of cytochrome c. On the other hand, if the ratio $B A X: B C L 2$ is lower, the cell death has being blocked. This ratio is often used as an indicator of cell susceptibility to apoptosis (Perlman et al., 1999; Nørgaard et al., 2008).

The heat shock response was higher for the HS goats than for the CT goats. Compared with CT goats, the HS goats' epithelial cells also expressed more of the $H S P B 1$ gene just before and after parturition. An antiapoptotic gene, HSPB1, is associated with cytochrome c and inhibits caspase- 3 activation, prevents cytoskeletal disruption, and acts as an antioxidant (Lanneau et al., 2007). This gene supports proliferation when several apoptosis signaling pathways are initiated. Although an effect on cell number cannot be ruled out, higher HSPB1 expression appears unlikely to be the main cause of the lower milk production of heat-stressed goats. This possibility is supported by the fact that the milk production response gradually fades during lactation, which is more compatible with a galactopoietic response occurring during lactation than with a mammogenic response occurring during the dry period.

Although the galactopoietic role of PRL in dairy ruminants has been controversial, there is now good evidence supporting this (Lacasse et al., 2016). Our finding that the expression of $P R L R$ is reduced by previous exposure to heat stress suggests a decrease in the responsiveness of the mammary gland to this hormone. An inverse relationship has been reported between circulating PRL and PRLR gene expression in the liver and lymphocytes of heat-stressed late-gestation cows (do Amaral et al., 2010, 2011). Although PRL was not measured in our study, it is well known that heat stress increases circulating concentrations of PRL in cattle (do Amaral et al., 2009) and goats (Sano et al., 1985). In a recent experiment, Tong et al. (2018) showed that a previous reduction in PRL concentration increased the subsequent galactopoietic response to PRL secretion stimulation.

Similar to heat stress, long-day photoperiod during the dry period also increases circulating PRL but decreases milk production in the subsequent lactation in cows (Auchtung et al., 2005; Lacasse et al., 2014) and goats (Mabjeesh et al., 2013). Accordingly, long-day photoperiod during the dry period has been associated the increase of PRL but with lower expression of PRL receptors (Auchtung et al., 2005) in the mammary gland, suggesting reduced responsiveness and sensitivity to PRL. The inhibition of PRL secretion during the drying-off period by dopamine agonist injection was reported to increase subsequent milk production (Baldwin et al., 2016; Lacasse et al., 2016). Although additional evidence is needed, the results of our study and other experiments suggest that a reduction in mammary gland responsiveness to PRL is likely involved in the negative effect of heat stress during the dry period on the subsequent lactation.

The mechanisms related to the reduction of mammary gland growth during the dry period resulting from heat stress and its effect on subsequent lactation are not completely stated. Nutrient availability at the mammary gland during heat stress may be another potential mechanism to explain the reduction in milk yield. It is known that heat stress enhances glucose uptake by peripheral tissues rather than mammary gland (Wheelock et al., 2010). Moreover, heat stress during the dry period reduced the DMI for about 0.5 $\mathrm{kg} / \mathrm{d}$ (Tao and Dahl, 2013); however, no change was noticed in plasma glucose, nonesterified fatty acids, BHB, and insulin (do Amaral et al., 2011; Tao et al., 2012). On the other hand, heat-stressed dry cows had higher gene expression of acetyl CoA carboxylase and 
fatty acid synthetase; these may indicate that the mammary gland cells recruit more energy toward fatty acid synthesis instead of doing mammary cell proliferation (Adin et al., 2009).

In conclusion, heat stress during late gestation reduces milk yield in the first half of the subsequent lactation. Even though the upregulation of apoptosis gene expression in HS goats was detected, the gradual loss of the effect of heat stress on milk production does not support an effect of heat stress on mammary epithelial cell number.

The present study suggests that the negative effect of heat stress in late gestation on subsequent milk yield is due in part to a decreased cell activity and is likely triggered by changes in PRL signaling in mammary epithelial cells. These findings highlight the negative consequences of heat stress during the dry period on milk production of dairy goats and suggest the need to provide thermal comfort during the dry period. Further work should be performed to further address this and other underlying mechanisms for the reduction in milk yield when animals are exposed to heat stress during the dry period.

\section{ACKNOWLEDGMENTS}

The authors sincerely thank the Department of Animal Reproduction, Faculty of Veterinary Medicine and Animal Science, University of São Paulo (Pirassununga, Brazil) for the use of its climatic chamber. This research was funded in part by the Coordination for the Improvement of Higher Education Personnel (CAPES, Brasilia, Brazil), the National Council of Technological and Scientific Development (CNPq 140517/2016-2, Brasilia, Brazil), and the São Paulo Research Foundation (FAPESP 2016/00123-3, São Paulo, Brazil). The authors are grateful to Mary Varcoe from the Translation Bureau, Public Works, and Government Services Canada, for her careful editing of this manuscript. The authors declare that there is no conflict of interest that could be perceived as prejudicing the impartiality of this research.

\section{REFERENCES}

Adin, G., A. Gelman, R. Solomon, I. Flamenbaum, M. Nikbachat, E. Yosef, A. Zenou, A. Shamay, Y. Feuermann, S. J. Mabjeesh, and J. Miron. 2009. Effects of cooling dry cows under heat load conditions on mammary gland enzymatic activity, intake of food and water, and performance during the dry period and after parturition. Livest. Sci. 124:189-195. https://doi.org/10.1016/j.livsci 2009.01.014.

Auchtung, T. L., A. G. Rius, P. E. Kendall, T. B. McFadden, and G. E. Dahl. 2005. Effects of photoperiod during the dry period on prolactin, prolactin receptor, and milk production of dairy cows. J. Dairy Sci. 88:121-127. https://doi.org/10.3168/jds.S0022 -0302(05)72669-2.

Avivar-Valderas, A., H. C. Wen, and J. A. Aguirre-Ghiso. 2014. Stress signaling and the shaping of the mammary tissue in development and cancer. Oncogene 33:5483-5490. https://doi.org/10.1038/onc .2013 .554 .

Bahr, B., H. L. Galan, and J. A. Arroyo. 2014. Decreased expression of phosphorylated placental heat shock protein 27 in human and ovine intrauterine growth restriction (IUGR). Placenta 35:404410. https://doi.org/10.1016/j.placenta.2014.03.001.

Baldwin, R. L., A. V. Capuco, C. M. Evock-Clover, P. Grossi, R. K. Choudhary, E. S. Vanzant, T. H. Elsasser, G. Bertoni, E. Trevisi, G. E. Aiken, and K. R. McLeod. 2016. Consumption of endophyteinfected fescue seed during the dry period does not decrease milk production in the following lactation. J. Dairy Sci. 99:7574-7589. https://doi.org/10.3168/jds.2016-10993.

Barrón-Bravo, O. G., A. J. Gutiérrez-Chávez, C. A. Ángel-Sahagún, H. H. Montaldo, L. Shepard, and M. Valencia-Posadas. 2013. Losses in milk yield, fat and protein contents according to different levels of somatic cell count in dairy goats. Small Rumin. Res. 113:421-431. https://doi.org/10.1016/j.smallrumres.2013.04.003.

Baudry, C., R. De Cremoux, C. Chartier, and G. Perrin. 1997. Incidence de la concentration cellulaire du lait de chèvre sur sa production et sa composition. Vet. Res. BioMed Cent. 28:277-286.

Belhadj Slimen, I., T. Najar, A. Ghram, and M. Abdrrabba. 2016. Heat stress effects on livestock: Molecular, cellular and metabolic aspects, a review. J. Anim. Physiol. Anim. Nutr. (Berl.) 100:401412. https://doi.org/10.1111/jpn.12379.

Bomfim, G. F., G. K. F. Merighe, S. A. de Oliveira, and J. A. Negrão. 2018. Effect of acute stressors, adrenocorticotropic hormone administration, and cortisol release on milk yield, the expression of key genes, proliferation, and apoptosis in goat mammary epithelial cells. J. Dairy Sci. 101:6486-6496. https://doi.org/10.3168/ jds.2017-14123.

Brasil, L. H. A., F. S. Wechesler, F. Baccari Júnior, H. C. Gonçalves, and I. A. Bonassi. 2000. Efeitos do estresse térmico sobre a produção, composição química do leite e respostas termorreguladoras de cabras da raça alpina. Rev. Bras. Zootec. 29:1632-1641. https://doi.org/10.1590/S1516-35982000000600006.

Brown, D. L., S. R. Morrison, and G. E. Bradford. 1988. Effects of ambient temperature on milk production of Nubian and Alpine goats. J. Dairy Sci. 71:2486-2490. https://doi.org/10.3168/jds .S0022-0302(88)79835-5.

Buffington, D. E., A. Collazo-Arocho, G. H. Canton, D. Pitt, W. W. Thatcher, and R. J. Collier. 1981. Black globe-humidity index (BGHI) as comfort equation for dairy cows. Trans. ASAE 81:711714. https://doi.org/10.13031/2013.34325.

Capuco, A. V., R. M. Akers, and J. J. Smith. 1997. Mammary growth in Holstein cows during the dry period: Quantification of nucleic acids and histology. J. Dairy Sci. 80:477-487. https://doi.org/10 .3168/jds.S0022-0302(97)75960-5.

Collier, R. J., B. J. Renquist, and Y. Xiao. 2017. A 100-year review: Stress physiology including heat stress. J. Dairy Sci. 100:1036710380. https://doi.org/10.3168/jds.2017-13676.

Dangi, S. S., S. K. Dangi, V. S. Chouhan, M. R. Verma, P. Kumar, G. Singh, and M. Sarkar. 2016. Modulatory effect of betaine on expression dynamics of HSPs during heat stress acclimation in goat (Capra hircus). Gene 575:543-550. https://doi.org/10.1016/j .gene.2015.09.031.

do Amaral, B. C., E. E. Connor, S. Tao, J. Hayen, J. Bubolz, and G. E. Dahl. 2010. Heat stress abatement during the dry period influences prolactin signaling in lymphocytes. Domest. Anim. Endocrinol. 38:38-45. https://doi.org/10.1016/j.domaniend.2009.07.005.

do Amaral, B. C., E. E. Connor, S. Tao, M. J. Hayen, J. W. Bubolz, and G. E. Dahl. 2009. Heat-stress abatement during the dry period: Does cooling improve transition into lactation? J. Dairy Sci. 92:5988-5999. https://doi.org/10.3168/jds.2009-2343.

do Amaral, B. C., E. E. Connor, S. Tao, M. J. Hayen, J. W. Bubolz, and G. E. Dahl. 2011. Heat stress abatement during the dry period influences metabolic gene expression and improves immune sta- 
tus in the transition period of dairy cows. J. Dairy Sci. 94:86-96. https://doi.org/10.3168/jds.2009-3004.

Du, J., H.-S. Di, L. Guo, Z.-H. Li, and G.-L. Wang. 2008. Hyperthermia causes bovine mammary epithelial cell death by a mitochondrial-induced pathway. J. Therm. Biol. 33:37-47. https://doi.org/ 10.1016/j.jtherbio.2007.06.002.

Flores, A., G. Mendoza, J. M. Pinos-Rodriguez, F. Plata, S. Vega, and R. Bárcena. 2009. Effects of rumen-protected methionine on milk production of dairy goats. Ital. J. Anim. Sci. 8:271-275. https:// doi.org/10.4081/ijas.2009.271.

Garrido, C., S. Gurbuxani, L. Ravagnan, and G. Kroemer. 2001. Heat Shock Proteins: Endogenous modulators of apoptotic cell death. Biochem. Biophys. Res. Commun. 286:433-442. https://doi.org/ 10.1006/bbrc.2001.5427.

Green, K. A., and C. H. Streuli. 2004. Apoptosis regulation in the mammary gland. Cell. Mol. Life Sci. 61:1867-1883. https://doi .org/10.1007/s00018-004-3366-y.

Hooper, H. B., P. dos Santos Silva, S. A. de Oliveira, G. K. F. Merighe, and J. A. Negrão. 2018. Acute heat stress induces changes in physiological and cellular responses in Saanen goats. Int. J. Biometeorol. 62:2257-2265. https://doi.org/10.1007/s00484-018-1630-3.

Hu, H., J. Wang, H. Gao, S. Li, Y. Zhang, and N. Zheng. 2016. Heatinduced apoptosis and gene expression in bovine mammary epithelial cells. Anim. Prod. Sci. 56:918-926. https://doi.org/10.1071/ AN14420.

IPCC. 2013. Climate Change 2013: The physical science basis. Contribution of working group I to the fifth assessment report of the Intergovernmental Panel on Climate Change 1535. https://doi.org/ 10.1017/CBO9781107415324.

Kadzere, C. T., M. R. Murphy, N. Silanikove, and E. Maltz. 2002. Heat stress in lactating dairy cows: A review. Livest. Prod. Sci. 77:59-91. https://doi.org/10.1016/S0301-6226(01)00330-X.

Karimi, M. T., G. R. Ghorbani, S. Kargar, and J. K. Drackley. 2015. Late-gestation heat stress abatement on performance and behavior of Holstein dairy cows. J. Dairy Sci. 98:6865-6875. https://doi .org/10.3168/jds.2014-9281.

Lacasse, P., S. Ollier, V. Lollivier, and M. Boutinaud. 2016. New insights into the importance of prolactin in dairy ruminants. J. Dairy Sci. 99:864-874. https://doi.org/10.3168/jds.2015-10035.

Lacasse, P., C. M. Vinet, and D. Petitclerc. 2014. Effect of prepartum photoperiod and melatonin feeding on milk production and prolactin concentration in dairy heifers and cows. J. Dairy Sci. 97:3589-3598. https://doi.org/10.3168/jds.2013-7615.

Lanneau, D., A. de Thonel, S. Maurel, C. Didelot, and C. Garrido. 2007. Apoptosis versus cell differentiation: Role of heat shock proteins HSP90, HSP70 and HSP27. Prion 1:53-60. https://doi.org/ 10.4161/pri.1.1.4059

Leitner, G., N. Silanikove, and U. Merin. 2008. Estimate of milk and curd yield loss of sheep and goats with intrammamary infection and its relation to somatic cell count. Small Rumin. Res. 74:221225. https://doi.org/10.1016/j.smallrumres.2007.02.009.

Levine, A. J. 1997. p53, the cellular gatekeeper for growth and division. Cell 88:323-331. https://doi.org/10.1016/s0092-8674(00)81871-1.

Livak, K. J., and T. D. Schmittgen. 2001. Analysis of relative gene expression data using real-time quantitative PCR and the $2^{-\Delta \Delta C T}$ method. Methods 25:402-408. https://doi.org/10.1006/meth.2001 1262 .

Mabjeesh, S. J., C. Sabastian, O. Gal-Garber, and A. Shamay. 2013. Effect of photoperiod and heat stress in the third trimester of gestation on milk production and circulating hormones in dairy goats. J. Dairy Sci. 96:189-197. https://doi.org/10.3168/jds.2012-5624.

Mader, T. L., M. S. Davis, and T. Brown-Brandl. 2006. Environmental factors influencing heat stress in feedlot cattle. J. Anim. Sci. 84:712-719. https://doi.org/10.2527/2006.843712x.

Maia, A. S. C., S. T. Nascimento, C. C. N. Nascimento, and K. G. Gebremedhin. 2016. Thermal equilibrium of goats. J. Therm. Biol. 58:43-49. https://doi.org/10.1016/j.jtherbio.2016.03.012.

Mohanarao, G. J., A. Mukherjee, D. Banerjee, M. Gohain, G. Dass, B. Brahma, T. K. Datta, R. C. Upadhyay, and S. De. 2014. HSP70 family genes and HSP27 expression in response to heat and cold stress in vitro in peripheral blood mononuclear cells of goat (Capra hircus). Small Rumin. Res. 116:94-99. https://doi.org/10.1016/j smallrumres. 2013.10.014.

Neuer, A., S. D. Spandorfer, P. Giraldo, S. Dieterle, Z. Rosenwaks, and S. S. Witkin. 2000. The role of heat shock proteins in reproduction. Hum. Reprod. Update 6:149-159. https://doi.org/10.1093/ humupd /6.2.149.

Nørgaard, J. V., P. K. Theil, M. T. Sørensen, and K. Sejrsen. 2008. Cellular mechanisms in regulating mammary cell turnover during lactation and dry period in dairy cows. J. Dairy Sci. 91:2319-2327. https://doi.org/10.3168/jds.2007-0767.

NRC. 2007. Nutrient Requirements of Small Ruminants: Sheep, Goats, Cervids and New World Camelids. National Academies Press, Washington, DC

Ohnishi, T., A. Takahashi, K. Ohnishi, and H. Matsumoto. 1999. DNA damage formation and p53 accumulation in mammalian cells exposed to the space environment. Biol. Sci. Space 13:82-87. https:/ /doi.org/10.2187/bss.13.82.

Ozaydin, T., E. Sur, Y. Oznurlu, I. Celik, and D. Uluisik. 2016. Immunohistochemical distribution of heat shock protein 70 and proliferating cell nuclear antigen in mouse placenta at different gestational stages. Microsc. Res. Tech. 79:251-257. https://doi.org/10.1002/ jemt.22624.

Paape, M. J., B. Poutrel, A. Contreras, J. C. Marco, and A. V. Capuco. 2001. Milk somatic cells and lactation in small ruminants. J. Dairy Sci. 84:E237-E244. https://doi.org/10.3168/jds.S0022 $-0302(01) 70223-8$

Pereira, G. M., B. B. de Souza, A. M. de A. Silva, J. V. B. Roberto, and C. M. B. de A. Silva. 2011. Avaliação do comportamento fisiológico de caprinos da raça Saanen no semiárido paraibano. Rev. Verde Agroecol. Desenvolv. Sustent. 6:83-88.

Perlman, H., X. Zhang, M. W. Chen, K. Walsh, and R. Buttyan. 1999 An elevated $\mathrm{Bax} / \mathrm{Bcl}-2$ ratio corresponds with the onset of prostate epithelial cell apoptosis. Cell Death Differ. 6:48-54. https:// doi.org/10.1038/sj.cdd.4400453.

Raynal-Ljutovac, K., A. Pirisi, R. de Crémoux, and C. Gonzalo. 2007. Somatic cells of goat and sheep milk: Analytical, sanitary, productive and technological aspects. Small Rumin. Res. 68:126-144. https://doi.org/10.1016/j.smallrumres.2006.09.012.

Rowson, A. R., K. M. Daniels, S. E. Ellis, and R. C. Hovey. 2012. Growth and development of the mammary glands of livestock: A veritable barnyard of opportunities. Semin. Cell Dev. Biol. 23:557566. https://doi.org/10.1016/j.semcdb.2012.03.018.

Sano, H., K. Ambo, and T. Tsuda. 1985. Blood glucose kinetics in whole body and mammary gland of lactating goats exposed to heat. J. Dairy Sci. 68:2557-2564. https://doi.org/10.3168/jds .S0022-0302(85)81137-1.

Sant'anna, A. C., and M. J. R. Paranhos da Costa. 2011. The relationship between dairy cow hygiene and somatic cell count in milk. J. Dairy Sci. 94:3835-3844. https://doi.org/10.3168/jds.2010-3951.

Santucci, P., and O. Maestrini. 1985. Body conditions of dairy goats in extensive systems of production: Method of estimation. Ann. Zootech. 34:473-474. https://doi.org/10.1051/animres:19850409.

Sarangi, S. 2018. Adaptability of goats to heat stress: A review. Pharma Innov. J. 7:1114-1126.

Sharif, A., and G. Muhammad. 2008. Somatic cell count as an indicator of udder health status under modern dairy production: A review. Pak. Vet. J. 28:194-200.

Shilja, S., V. Sejian, M. Bagath, A. Mech, C. G. David, E. K. Kurien, G. Varma, and R. Bhatta. 2016. Adaptive capability as indicated by behavioral and physiological responses, plasma HSP70 level, and PBMC HSP70 mRNA expression in Osmanabadi goats subjected to combined (heat and nutritional) stressors. Int. J. Biometeorol. 60:1311-1323. https://doi.org/10.1007/s00484-015-1124-5.

Shochet, G. E., O. Komemi, D. Sadeh-Mestechkin, M. Pomeranz, A. Fishman, L. Drucker, M. Lishner, and S. T. Matalon. 2016. Heat shock protein-27 (HSP27) regulates STAT3 and eIF4G levels in first trimester human placenta. J. Mol. Histol. 47:555-563. https:/ /doi.org/10.1007/s10735-016-9699-7.

Silanikove, N. 2000. The physiological basis of adaptation in goats to harsh environments. Small Rumin. Res. 35:181-193. https://doi .org/10.1016/S0921-4488(99)00096-6. 
Silanikove, N., and D. N. Koluman. 2015. Impact of climate change on the dairy industry in temperate zones: Predications on the overall negative impact and on the positive role of dairy goats in adaptation to earth warming. Small Rumin. Res. 123:27-34. https://doi .org/10.1016/j.smallrumres.2014.11.005.

Silva, R. G. 2000. Introdução à Bioclimatologia Animal. Ed. Nobel, São Paulo, Brazil.

Tao, S., J. W. Bubolz, B. C. do Amaral, I. M. Thompson, M. J. Hayen, S. E. Johnson, and G. E. Dahl. 2011. Effect of heat stress during the dry period on mammary gland development. J. Dairy Sci. 94:5976-5986. https://doi.org/10.3168/jds.2011-4329.

Tao, S., and G. E. Dahl. 2013. Invited review: Heat stress effects during late gestation on dry cows and their calves. J. Dairy Sci. 96:4079-4093. https://doi.org/10.3168/jds.2012-6278.

Tao, S., I. M. Thompson, A. P. A. Monteiro, M. J. Hayen, L. J. Young, and G. E. Dahl. 2012. Effect of cooling heat-stressed dairy cows during the dry period on insulin response. J. Dairy Sci. 95:50355046. https://doi.org/10.3168/jds.2012-5405.
Tong, J. J., I. M. Thompson, X. Zhao, and P. Lacasse. 2018. Effect of the concentration of circulating prolactin on dairy cows' responsiveness to domperidone injection. J. Dairy Sci. 101:2579-2587. https://doi.org/10.3168/jds.2017-13828.

Urdaz, J. H., M. W. Overton, D. A. Moore, and J. E. P. Santos. 2006. Technical note: Effects of adding shade and fans to a feedbunk sprinkler system for preparturient cows on health and performance. J. Dairy Sci. 89:2000-2006. https://doi.org/10.3168/jds .S0022-0302(06)72267-6.

West, J. W. 2003. Effects of heat-stress on production in dairy cattle. J. Dairy Sci. 86:2131-2144. https://doi.org/10.3168/jds.S0022 -0302(03)73803-X.

Wheelock, J. B., R. P. Rhoads, M. J. VanBaale, S. R. Sanders, and L. H. Baumgard. 2010. Effects of heat stress on energetic metabolism in lactating Holstein cows. J. Dairy Sci. 93:644-655. https://doi .org/10.3168/jds.2009-2295. 